\title{
THE EFFECT OF ANTENATAL CORTICOSTEROID ON INCIDENCE OF RESPIRATORY DISTRESS SYNDROME ACCORDING TO MATERNAL BODY MASS INDEX
}

\author{
Eun Ju Jo, MD, Hye-Min Kwak, MD, Hyun-Young Ji, MD, Hyun-Hwa Cha, MD, Suk-Joo Choi, MD, Soo-young \\ Oh, MD, Cheong-Rae Roh, MD, Jong-Hwa Kim, MD \\ Department of Obstetrics and Gynecology, Samsung Medical Center, Sungkyunkwan University School of Medicine, Seoul, Korea
}

\begin{abstract}
Objective
To investigate the effects of antenatal corticosteroid (ACS) on incidence of neonatal respiratory distress syndrome (RDS) according to maternal body mass index (BMI).
\end{abstract}

\section{Methods}

We retrospectively reviewed the medical records of 715 singleton pregnant women who delivered between $24+0$ and $34+0$ weeks of gestation, from January 1996 to December 2006. Subjects were categorized into three groups according to ACS exposure: a nonuser group $(n=244)$, a single-course group $(n=377)$ and a multiple-course group $(n=94)$. Subjects were re-categorized into three groups according to maternal BMI at admission: group $1\left(B M l<23.0 \mathrm{~kg} / \mathrm{m}^{2}, \mathrm{n}=234\right)$, group $\left.2(B M I) 23.0-24.9 \mathrm{~kg} / \mathrm{m}^{2}, \mathrm{n}=166\right)$ and group $3\left(\mathrm{BMI} \geq 25.0 \mathrm{~kg} / \mathrm{m}^{2}, \mathrm{n}=315\right)$. Univariate and multiple logistic regression analyses were used for the statistical analysis.

\section{Results}

Overall, the incidence of RDS was significantly lower in ACS-user groups than the non-user group, with lowest incidence in the multiple-course group (non-user vs. single-course vs. multiple-course: $44.3 \%$ vs. $41.1 \%$ vs. $11.7 \%, P<0.001$ ). The incidence of RDS was not different among the three BMI groups. Multiple logistic regression analysis showed that single- and multiple-course of ACS was significantly associated with reduced incidence of RDS: single-course, odds ratio (OR) $0.593,95 \%$ confidence interval (CI) 0.373 , 0.942; multiple-course, OR $0.085,95 \% \mathrm{Cl} 0.034,0.213$. However, maternal BMI was not associated with reduced incidence of RDS with different ACS-courses ( $P$ for interaction $=0.690)$.

\section{Conclusion}

ACS therapy, especially when multiple-course was used, was significantly associated with reduced incidence of RDS, but maternal BMI did not influence its effectiveness.

Keywords: Preterm delivery; Antenatal corticosteroid; Respiratory distress syndrome; Maternal body mass index

1972년 Liggins와 Howie [1]에 의해 조산아의 다양한 합병증을 줄이 는데 산전 부신피질호르몬의 효용성에 대해 발표한 이후 조산에서는 산 전 부신피질호르몬의 투여에 대해 많은 연구가 이루어졌다. 임신 24주 에서 34주 사이에 조산의 위험이 있는 임신부에게 산전 부신피질호르 몬을 투여하는 것은 태아의 폐성숙을 촉진시켜 신생아 호흡곤란증후 군을 예방하고, 신생아 사망, 괴사성 장염, 뇌실내 출혈의 위험을 감소 시킨다[2]. 1994년 National Institute of Child Health and Development (NICHD)의 Consensus Development Conference에서는 조산의 위험이 높은 임신부에게 산전 부신피질호르몬의 일회 투여를 조산아 합병증 예 방을 위한 효과적인 치료법으로 권고하였다[3].
Received: 2011. 5.25. Revised: 2011. 7.19. Accepted: 2011. 9. 9. Corresponding author: Suk-Joo Choi, MD

Department of Obstetrics and Gynecology, Samsung Medical Center, Sungkyunkwan University School of Medicine, 50 Ilwondong, Gangnam-gu, Seoul 135-710, Korea Tel: +82-2-3410-3546 Fax: +82-2-3410-0630 E-mail:drmaxmix.choi@samsung.com

This is an Open Access article distributed under the terms of the Creative Commons Attribution Non-Commercial License (http://creativecommons.org/licenses/ by-nc/3.0/) which permits unrestricted non-commercial use, distribution, and reproduction in any medium, provided the original work is properly cited.

Copyright $\odot$ 2011. Korean Society of Obstetrics and Gynecology 


\section{KOREAN JOURNAL OF OBSTETRICS \& GYNECOLOGY}

Eun Ju Jo, et al. The effect of ACS and maternal BMI

산전 부신피질호르몬의 약의 종류와 용법은 NICHD 및 미국산부인과 학회에서 권고한 바에 따라 dexamethasone $6 \mathrm{mg}$ 을 12시간 간격으로 4회 근주하는 것 또는 betamethasone $12 \mathrm{mg}$ 을 24시간 간격으로 2회 근주하는 것의 두 가지 방법 중 하나를 선택하는 것이 일반적이다 $[1,4]$. 근주한 약의 흡수 및 효과는 여러 가지 요인에 따라 달라질 수 있고, 특 히 환자의 체중 또는 비만도가 중요한 요인 중 하나이다. 비만도 또는 체질량지수는 약의 분포용적에 영향을 미친다. Dexamethasone 또는 betamethasone는 일차적으로 간에서 대사될 뿐 아니라 간과 주위 조직 에서도 대사된다[5]. 지방의 무게에 따른 혈류량은 비만인 경우에 정상 보다 더 많고 혈류량은 분포용적에 영향을 미치므로 비만이 흡수에 영 향을 주지 못할지라도 조직의 분포와 약의 배출에는 영향을 미친다.

본원에서 시행한 연구결과에 따르면 단태임신에서는 산전 부신피질 호르몬이 조산아의 신생아 호흡곤란증후군 예방을 비롯한 주산기 예후 를 호전시키는 효과가 있었으나[6] 다태임신에서는 산전 부신피질호르 몬의 일회 또는 다회 요법이 주산기 예후를 호전시키지 못하는 것으로 나타났다[7]. 이는 다른 다태임신 연구에서 나타난 결과와 유사한 결과 였다[8-10]. 이러한 이유로 다태임신부가 단태임신부에 비해 체질량지 수가 더 크고 분포용적이 크거나 혈장량이 많기 때문이라는 가설이 제 기되고 있으며 임신부의 비만도 또는 체질량지수와 관계 없이 산전 부 신피질호르몬을 같은 용량으로 투여해도 그 용량이 충분한지에 대한 의 문이 제기되었다. 본 연구에서는 임신부의 체질량지수에 따라 부신피질 호르몬 일회 또는 다회 투여가 신생아 호흡곤란증후군을 비롯한 조산아 합병증 발생에 미치는 영향을 알아보고자 하였다.

\section{연구대상 및 방법}

\section{1. 연구대상 및 디자인}

본 연구는 후향적 관찰 연구로 1996년 1월부터 2006년 12월까지 임 신 24주 0 일에서 33주 6일 사이에 입원하여 34주 이전에 분만한 임신 부를 대상으로 하여 임신부와 신생아의 입원기록 및 퇴원 요약 등을 고 찰하였다. 입원 시 진단은 1) 조기진통 또는 자궁경관무력증, 2) 조기 양막파수, 3) 모성 또는 태아 측 적응증으로 분류하였고, 모성 또는 태 아 측 적응증은 전자간증을 비롯한 고혈압성 질환, 전치태반에 의한 출 혈, 자궁내 태아 발육지연, 양수과소증, 양수과다증 등이었다. 이 중 다 태임신과 자궁내 태아사망, 주요 태아 기형, 태반조기박리, 임신전 당뇨 (pregestational diabetes), 중증의 내과적-외과적 모성 질환을 제외하였 다. 연구 대상에 포함된 임신부는 부신피질호르몬 투여 유무에 따라 비 사용군과 사용군으로 분류하였고, 사용군은 다시 부신피질호르몬을 1 회 투여 받은 군(일회 사용군)과 부신피질호르몬을 2회 이상 투여 받은 군 (다회 사용군)으로 각각 분류하였다. 부신피질호르몬은 dexamethasone 또는 betamethasone 중 하나를 사용하였으며 서로 다른 약물 선택에 따른 적응증은 없었다. Dexamethasone은 $6 \mathrm{mg}$ 을 12시간 간격으로 4 회 근주하는 것을, betamethasone은 $12 \mathrm{mg}$ 을 24시간 간격으로 2회 근 주하는 것을 각각 1 회(1주기)의 완전 투여요법으로 하였다. 부신피질호
르몬 사용군 중에서 1 회의 완전 투여요법이 이루어지지 않은 상태에서 분만을 한 경우는 제외하였다. 부신피질호르몬의 다회 투여는 초기 1 회 사용 후 7일이 지난 후 임상적 양상을 관찰하여 조산의 위험성과 임신 부의 상태에 따라 결정하였다. 연구 대상은 입원 당시 체질량지수(body mass index, BMI)에 따라 1군 $\left(\mathrm{BMl}<23.0 \mathrm{~kg} / \mathrm{m}^{2}\right), 2$ 군(BMl 23.0-24.9 $\left.\mathrm{kg} / \mathrm{m}^{2}\right)$, 3군 $\left(\mathrm{BM} \geq 25.0 \mathrm{~kg} / \mathrm{m}^{2}\right)$ 세 군으로 재분류하였다.

연구분석 대상에 포함된 임신부들의 연령, 분만력, 입원 적응증, 입원 시 임신 주수, 분만 시 임신 주수, 입원 후 분만까지의 기간입원-분만 잠복기), 분만 방법 및 융모양막염의 유무를 조사하였다. 임상적 융모양 막염은 Gibbs 등[11]이 제시한 기준에 따라 다른 원인이 배제된 상태에 서 $37.8^{\circ} \mathrm{C}$ 이상의 발열이 있으면서 임신부의 백혈구 증가 $(\geq 15,000 /$

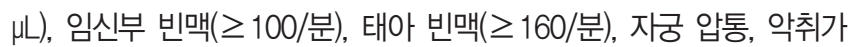
나는 질 분비물 중에서 2가지 이상의 징후가 있을 때로 정의하였고, 조 직학적 융모양막염은 태반조직 검사상 급성 염증성 변화를 검사하여 융 모양막염이 확진된 경우로 하였다.

\section{2. 신생아 이환의 진단}

연구분석 대상 임신부들에게서 출생한 신생이들의 입원 기록 및 퇴 원 요약을 토대로 출생 시 임신 주수, 출생 체중, 두위, 복위, 임신 주수 에 비한 저체중아(small-for-gestational-age) 여부, 1분 및 5분 아프가 점수, 신생아 사망, 신생아 중환자실 입원 유무와 인공호흡기 치료 유무 를 조사하였고, 신생아 중환자실 입원기간은 총 입원일수로, 인공호흡기 사용기간은 총 사용일수로 각각 계산하였다. 신생아 사망은 신생아 중 환자실 입원 중 사망으로 정의하였다. 각 조산아 합병증의 진단 기준은 이전에 발표된 산전 부신피질호르몬의 다회 요법이 주산기 예후에 미 치는 영향에 대한 논문에 제시한 기준을 따랐다[6]. 신생아 복합 합병증 (composite morbidity)은 신생아 중환자실 입원 기간 중 신생아 사망, 신 생아 호흡곤란증후군, 기관지폐 이형성증, 뇌실주위 백질연화증, 3도 이 상의 뇌실내 출혈, 3 도 이상의 미숙아 망막증, 2 기 이상의 괴사성 장염, 의증 또는 증명된 조기 및 만기 신생아 패혈증 중 하나 이상의 조산아 합병증이 발생한 경우로 정의하였다.

\section{3. 통계학적 분석}

연속형 변수는 일원성 분산분석(one way analysis of variance) 또 는 Kruskal-Wallis test를 통해 세 군 간의 차이를 검정하였고, 최소 유의차 검증(least significant difference)를 사용하여 사후 검증(posthoc analysis)을 하였다. 세 군 간의 연속형 변수의 증감 경향은 Jonckheere-Terpstra test를 사용하였다. 범주형 변수는 chi-square test 또는 Fisher's exact test를 이용하여 분석하였고, 세 군 간의 범주형 변수의 증감 경향은 선형대 선형결합(linear-by-linear association)을 이 용하여 검정하였다.

산전 부신피질호르몬의 1 회 또는 다회 투여 및 임신부의 체질량지수 가 조산아의 신생아 호흡곤란증후군의 발생에 독립적으로 미치는 영 향을 분석하기 위하여 다중로짓 회귀분석(multiple logistic regression analysis)을 사용하였다. 다중회귀분석에서 교란변수는 단변량 분석에 
KJOG Vol. 54, No. 10, 2011

Table 1. Demographic characteristics of the patients and pregnancy outcomes according to antenatal steroid exposure

\begin{tabular}{|c|c|c|c|c|}
\hline & $\begin{array}{l}\text { Non-user } \\
(n=244)\end{array}$ & $\begin{array}{c}\text { Single-course } \\
(\mathrm{n}=377)\end{array}$ & $\begin{array}{l}\text { Multiple-course } \\
(\mathrm{n}=94)\end{array}$ & $P$-value \\
\hline Age (yr) & $30.6 \pm 4.4$ & $30.9 \pm 3.8$ & $31.1 \pm 3.7$ & 0.433 \\
\hline Nulliparity & $98(40.2)$ & $181(48.0)$ & $49(52.1)$ & 0.068 \\
\hline History of preterm delivery & $31(12.7)$ & $53(14.1)$ & $13(13.8)$ & 0.888 \\
\hline Body mass index $\left(\mathrm{kg} / \mathrm{m}^{2}\right)$ & & & & 0.834 \\
\hline$<23.0$ & $76(31.1)$ & $127(33.7)$ & $31(33.0)$ & \\
\hline $23.0-24.9$ & $56(23.0)$ & $94(24.1)$ & $19(20.2)$ & \\
\hline$\geq 25.0$ & $112(45.9)$ & $159(42.2)$ & $44(46.8)$ & \\
\hline Indication for admission & & & & $<0.001$ \\
\hline PTL or $\| O C$ & $124(50.8)$ & $133(35.3)$ & $33(35.1)$ & \\
\hline PPROM & $70(28.7)$ & $168(44.6)$ & $47(50.0)$ & \\
\hline Maternal or fetal indications & $50(20.5)$ & $76(20.2)$ & $14(14.9)$ & \\
\hline Gestational age at admission (wk) & $30.1 \pm 2.8$ & $29.2 \pm 2.9$ & $28.5 \pm 2.3$ & $<0.001^{\mathrm{a}}$ \\
\hline Gestational age at delivery (wk) & $30.4 \pm 2.8$ & $30.3 \pm 2.7$ & $31.3 \pm 2.0$ & $0.003^{b}$ \\
\hline Admission-to-delivery interval (day) & $0[0-52]$ & $5[2-65]$ & $14.5[9-60]$ & $<0.001^{\mathrm{a}}$ \\
\hline Hypertensive disorders $^{c}$ & $44(18.0)$ & $64(17.0)$ & $11(11.7)$ & 0.364 \\
\hline Gestational DM & $12(4.9)$ & $14(3.7)$ & $2(2.1)$ & 0.474 \\
\hline Type of ACS used & & & & 0.226 \\
\hline Dexamethasone & - & $93(24.7)$ & $29(30.9)$ & \\
\hline Betamethasone & - & $283(75.3)$ & $65(69.1)$ & \\
\hline Cesarean delivery & $136(55.7)$ & $210(55.7)$ & $49(52.1)$ & 0.808 \\
\hline Clinical chorioamnionitis & $19(7.8)$ & $22(5.8)$ & $7(7.4)$ & 0.608 \\
\hline Histologic chorioamnionitis & $60 / 178(33.7)$ & $135 / 348(38.8)$ & $32 / 84(38.1)$ & 0.512 \\
\hline
\end{tabular}

Bolding denotes significant findings.

Data are presented by mean \pm standard deviation or number $(\%)$ or median [range].

PTL, preterm labor; IIOC, incompetent internal os of cervix; PPROM, preterm premature rupture of membranes; DM, diabetes mellitus; ACS, antenatal corticosteroid.

a Jonckheere-Terpstra test, $P<0.001$.

${ }^{b}$ non-user vs. multiple-course, $P<0.05$; single-course vs. multiple-course, $P<0.05$.

'gestational hypertension, mild \& severe preeclampsia, superimposed preeclampsia, eclampsia, chronic hypertension.

서 각 군간 통계적인 차이가 있는 변수들로 하였다. 임신부의 체질량 지수와 산전 부신피질호르몬 투여 유무의 교호작용을 분석하기 위해 Deviance table을 분석하였다. $P$-value가 0.05 미만인 경우 통계학적 으로 유의한 것으로 간주하였다.

\section{결 과}

총 715 명의 임신부가 최종 연구 분석 대상에 포함되었다. 이 중 부신 피질호르몬 투여를 받지 않은 비사용군에 244명, 사용군에 471명이 포 함되었고, 사용군은 일회 사용군에 377 명, 다회 사용군에 94 명이 각각 포함되었다.
먼저 산전 부신피질호르몬의 일회 또는 다회 투여가 주산기 예후에 미치는 영향을 분석하였다. 산전 부신피질호르몬 비사용군, 일회 사용군 및 다회 사용군은 입원의 적응증, 입원 시 임신 주수, 분만 시 임신 주 수 및 입원-분만 잠복기가 차이가 있었고, 그 외의 임신부 특성이나 임 신 결과는 세 군 간 차이가 없었다(Table 1). 신생아의 출생 체중 및 복 위는 다회 사용군이 일회 사용군과 비사용군에 비해 컸다(Table 2). 4점 미만의 1 분 아프가 점수 및 7 점 미만의 5 분 아프가 점수의 신생아는 비 사용군에 비해 일회 사용군 및 다회 사용군이 유의하게 적었다. 인공호 흡기 사용률은 비사용군이 가장 높았으며, 일회 사용군, 다회 사용군 순 으로 감소하는 경향을 보였다. 그러나 인공호흡기 사용기간은 세 군 간 에 유의한 차이가 없었다. 세 군 중 신생아 호흡곤란증후군 및 기관지폐 이형성증의 발생 빈도는 다회 사용군에서 가장 적게 발생하였다. 그러 


\section{KOREAN JOURNAL OF OBSTETRICS \& GYNECOLOGY}

Eun Ju Jo, et al. The effect of ACS and maternal BMI

Table 2. Perinatal outcomes of the preterm neonates according to antenatal steroid exposure

\begin{tabular}{|c|c|c|c|c|}
\hline & $\begin{array}{l}\text { Non-user } \\
(\mathrm{n}=244)\end{array}$ & $\begin{array}{c}\text { Single-course } \\
(\mathrm{n}=377)\end{array}$ & $\begin{array}{l}\text { Multiple-course } \\
\quad(n=94)\end{array}$ & $P$-value \\
\hline Gestational age at delivery (wk) & $30.4 \pm 2.8$ & $30.2 \pm 2.7$ & $31.3 \pm 2.0$ & $0.003^{\mathrm{a}}$ \\
\hline Sex (male) & $142(58.2)$ & $198(52.5)$ & $59(62.8)$ & 0.131 \\
\hline Birth weight $(\mathrm{kg})$ & $1.51 \pm 0.52$ & $1.52 \pm 0.54$ & $1.69 \pm 0.45$ & $0.011^{\mathrm{a}}$ \\
\hline Head circumference $(\mathrm{cm})$ & $28.1 \pm 3.1$ & $27.9 \pm 3.2$ & $28.8 \pm 2.8$ & 0.067 \\
\hline Abdominal circumference $(\mathrm{cm})$ & $23.23 \pm 3.2$ & $23.4 \pm 3.3$ & $24.5 \pm 3.1$ & $0.004^{\mathrm{a}}$ \\
\hline SGA & $24(9.8)$ & $37(9.8)$ & $8(8.5)$ & 0.921 \\
\hline 1 min apgar score $<4$ & $70(28.8)$ & $49(13.0)$ & $14(14.9)$ & $<0.001$ \\
\hline 5 min apgar score $<7$ & $78(32.1)$ & $55(14.6)$ & $12(12.8)$ & $<0.001$ \\
\hline NICU admission & $240(98.4)$ & $369(97.9)$ & $94(100)$ & 0.358 \\
\hline Duration of NICU stay (day) & 35 [2-199] & $34[1-318]$ & $28[3-275]$ & 0.060 \\
\hline Ventilator treatment & $153(62.7)$ & $201(53.5)$ & $37(39.4)$ & $<0.001$ \\
\hline Duration of assisted ventilation (day) & $5[1-197]$ & $5[1-317]$ & $3[1-213]$ & 0.102 \\
\hline Neonatal mortality & $15(6.1)$ & $14(3.7)$ & $2(2.1)$ & 0.184 \\
\hline Respiratory distress syndrome & $108(44.3)$ & $155(41.1)$ & $11(11.7)$ & $<0.001$ \\
\hline Bronchopulmonary dysplasia & $48(19.7)$ & $83(22.1)$ & $6(6.4)$ & 0.002 \\
\hline Periventricular leukomalacia & $8(3.3)$ & $13(3.5)$ & $2(2.1)$ & 0.806 \\
\hline Intraventricular hemorrhage ( $\geq$ grade 3 ) & $7(2.9)$ & $12(3.2)$ & $0(0)$ & 0.221 \\
\hline Retinopathy of prematurity ( $\geq$ grade 3 ) & $16(6.6)$ & $24(6.4)$ & $3(3.2)$ & 0.463 \\
\hline Necrotizing enterocolitis ( $\geq$ stage 2 ) & $8(3.3)$ & $6(1.6)$ & $1(1.1)$ & 0.272 \\
\hline Suspected or proven early sepsis & $13(5.3)$ & $33(8.8)$ & $6(6.4)$ & 0.255 \\
\hline Suspected or proven late sepsis & $17(7.0)$ & $34(9.0)$ & $5(5.3)$ & 0.399 \\
\hline Composite morbidity ${ }^{b}$ & $132(54.1)$ & $208(55.2)$ & $29(30.9)$ & 0.001 \\
\hline
\end{tabular}

Bolding denotes significant findings.

Data are presented by mean \pm standard deviation or number $(\%)$ or median [range].

SGA, small-for-gestational-age; NICU, neonatal intensive care unit.

${ }^{a}$ Non-user vs. multiple-course, $P<0.05$; single-course vs. multiple-course, $P<0.05$.

${ }^{b}$ Defined as having more than one of the following: neonatal death, respiratory distress syndrome, bronchopulmonary dysplasia, periventricular leukomalacia, intraventricular hemorrhage ( $\geq$ grade 3 ), retinopathy of prematurity $(\geq$ grade 3$)$, necrotizing enterocolitis ( $\geq$ stage 2$)$, suspected or proven early and late neonatal sepsis.

나 그 외의 조산아 합병증의 발생 빈도는 세 군 간에 유의한 차이가 없 었다. 전반적인 신생아의 조산 합병증의 발생 빈도를 분석하기 위한 지 표인 신생아 복합 합병증의 위험은 다회 사용군의 신생아가 가장 낮았 다(Table 2). 각 군에서 betamethasone 또는 dexamethasone의 사용 빈 도는 차이가 없었다. Betamethasone 사용군과 dexamethasone 사용군 사이에 신생아 호흡곤란증후군의 발생빈도는 차이가 있었으나 두 군의 산모 연령, 입원 시 임신 주수, 분만 시 임신 주수, 입원 적응증, 조직학 적 융모양막염, 저체중아가 서로 다르기 때문에 이를 다중로짓회귀분석
으로 보정한 결과 부신피질호르몬의 종류는 신생아 호흡곤란증후군의 발생과 통계적으로 의미 있는 연관성이 없었다(odds ratio [OR] 1.769 95\% confidence interval [CI] 0.932, 3.356).

임신부의 입원 당시 체질량지수에 따라 1 군 $\left(\mathrm{BM}<<23.0 \mathrm{~kg} / \mathrm{m}^{2}\right), 2$ 군 (BM 23.0-24.9 kg/m²), 3군(BMl>25.0 kg/m²)으로 분류하고 각 군별로 임신부의 입원 당시 인구학적 특성 및 임신 경과를 비교하였다(Table 3). 임신부의 연령 및 입원 적응증, 입원 시 임신 주수에는 세 군 간에 유의 한 차이가 있었으나 분만 시 임신 주수는 세 군 간 유의한 차이가 없었 


\title{
KOREAN JOURNAL OF OBSTETRICS \& GYNECOLOGY
}

\author{
KJOG Vol. 54, No. 10, 2011
}

Table 3. Demographic characteristics of the patients and pregnancy outcomes according to maternal body mass index

\begin{tabular}{|c|c|c|c|c|}
\hline & $\begin{array}{c}\text { Group } 1 \\
\left(\mathrm{BMI}<23 \mathrm{~kg} / \mathrm{m}^{2}\right) \\
(\mathrm{n}=1234)\end{array}$ & $\begin{array}{c}\text { Group } 2 \\
\left.\text { (BMI } 23-24.9 \mathrm{~kg} / \mathrm{m}^{2}\right) \\
(\mathrm{n}=166)\end{array}$ & $\begin{array}{c}\text { Group } 3 \\
\left(B M I \geq 25 \mathrm{~kg} / \mathrm{m}^{2}\right) \\
(\mathrm{n}=315)\end{array}$ & $P$-value \\
\hline Age (yr) & $29.9 \pm 3.8$ & $31.2 \pm 3.7$ & $31.2 \pm 4.2$ & $<0.001^{\mathrm{a}}$ \\
\hline Nulliparity & $126(53.8)$ & $99(59.6)$ & $162(51.4)$ & 0.227 \\
\hline History of preterm delivery & $26(11.1)$ & $26(15.7)$ & $45(14.3)$ & 0.375 \\
\hline Indication for admission & & & & $<0.001$ \\
\hline PTL or $\| O C$ & $123(52.6)$ & $69(41.6)$ & $98(31.1)$ & \\
\hline PPROM & $86(36.8)$ & $75(45.2)$ & $124(39.4)$ & \\
\hline Maternal or fetal indications & $25(10.7)$ & $22(13.3)$ & $92(29.5)$ & \\
\hline Gestational age at admission (wk) & $29.0 \pm 2.9$ & $29.4 \pm 2.8$ & $29.7 \pm 2.7$ & $0.015^{\mathrm{ab}}$ \\
\hline Gestational age at delivery (wk) & $30.2 \pm 2.7$ & $30.4 \pm 2.8$ & $30.7 \pm 2.6$ & $0.059^{a}$ \\
\hline Admission-to-delivery interval (day) & $4[0-65]$ & $4[0-60]$ & $4[0-65]$ & 0.794 \\
\hline Use of ACS & & & & 0.834 \\
\hline Non-user & $76(32.5)$ & $56(33.7)$ & $112(35.6)$ & \\
\hline Single-course & $127(54.3)$ & $91(54.8)$ & $159(50.5)$ & \\
\hline Multiple-course & $31(13.2)$ & $19(11.4)$ & $44(14.0)$ & \\
\hline Type of ACS used & & & & 0.671 \\
\hline Dexamethasone & $37(23.4)$ & $30(27.3)$ & $55(27.2)$ & \\
\hline Betamethasone & $121(76.6)$ & $80(72.7)$ & $147(72.8)$ & \\
\hline Hypertensive disorders $^{c}$ & $15(6.4)$ & $17(10.2)$ & $87(27.6)$ & $<0.001$ \\
\hline Gestational DM & $3(1.3)$ & $6(3.6)$ & $19(6.0)$ & 0.017 \\
\hline Cesarean delivery & $118(50.4)$ & $77(46.4)$ & $200(63.5)$ & $<0.001$ \\
\hline Clinical chorioamnionitis & $8(3.4)$ & $15(9.0)$ & $25(7.9)$ & 0.044 \\
\hline Histologic chorioamnionitis & $81 / 193(42.0)$ & $54 / 143(37.8)$ & $92 / 274(33.6)$ & 0.179 \\
\hline
\end{tabular}

Bolding denotes significant findings.

Data are presented by mean \pm standard deviation or number (\%) or median [range].

PTL, preterm labor; IIOC, incompetent internal os of cervix; PPROM, preterm premature rupture of membranes; ACS, antenatal corticosteroid; DM, diabetes mellitus.

a Jonckheere-Terpstra test, $P<0.05$.

${ }^{b}$ Non-user vs. multiple-course, $P<0.05$.

'Gestational hypertension, mild \& severe preeclampsia, superimposed preeclampsia, eclampsia, chronic hypertension.

다. 임신성 고혈압성 질환, 임신성 당뇨, 임상적 융모양막염, 제왕절개수 술률도 유의한 차이가 있었고, 특히 2군 및 3군에서 임신성 고혈압성 질 환, 임신성 당뇨, 제왕절개수술률이 높았다.

임신부의 체질량지수에 따른 세 군의 신생아의 예후에 대한 결과를 분석하였다(Table 4). 출생 시 임신 주수, 성별, 임신 주수에 비한 저체중 아 및 두위, 출생 체중, 신생아의 복위는 세 군에서 차이가 없었다. 전기 신생아 패혈증을 제외한 1 분 아프가 점수, 5 분 아프가 점수, 신생아 중 환자실 입원율 및 입원기간, 인공호흡기 사용률, 인공호흡기 사용기간, 신생아 호흡곤란증후군, 기관지폐 이형성증, 뇌실 주위 백질연화증, 괴 사성 장염, 뇌실내 출혈, 미숙아 망막증, 말기 신생아 패혈증 및 신생아 복합 합병증의 발생 빈도는 세 군 간에 유의한 차이가 없었다.
각 체질량지수군을 산전 부신피질호르몬 비 사용군, 일회 사용군과 다회 사용군으로 분류하여 신생아 호흡곤란증후군 및 신생아 복합 합병 증의 발생 빈도를 분석하였다(Table 5). 각 체질량지수군에서 산전 부신 피질호르몬의 투여군에 따른 신생아 호흡곤란증후군의 발생 빈도는 유 의한 차이가 있었고, 특히 다회 사용군에서 그 발생 빈도가 가장 낮았 다. 신생아 복합 합병증의 발생 빈도도 유사한 결과를 보였다. 그러나 산전 부신피질호르몬 비사용군, 일회 사용군 및 다회 사용군 각각에서 각 체질량지수군에 따른 신생아 호흡곤란증후군 및 신생아 복합 합병증 의 발생 빈도는 차이가 없었다. 신생아 호흡곤란증후군의 발생에 있어 임신부의 체질량지수군과 산전 부신피질호르몬 사용군의 교호작용은 유의하지 않았다 $(P=0.690)$. 


\section{KOREAN JOURNAL OF OBSTETRICS \& GYNECOLOGY}

Eun Ju Jo, et al. The effect of ACS and maternal BMI

Table 4. Perinatal outcomes of the preterm neonates according to maternal body mass index

\begin{tabular}{|c|c|c|c|c|}
\hline & $\begin{array}{c}\text { Group } 1 \\
\left(\mathrm{BMI}<23 \mathrm{~kg} / \mathrm{m}^{2}\right) \\
(\mathrm{n}=234)\end{array}$ & $\begin{array}{c}\text { Group } 2 \\
\left.\text { (BMI } 23-24.9 \mathrm{~kg} / \mathrm{m}^{2}\right) \\
(\mathrm{n}=166)\end{array}$ & $\begin{array}{c}\text { Group } 3 \\
\left(\mathrm{BMI} \geq 25 \mathrm{~kg} / \mathrm{m}^{2}\right) \\
(\mathrm{n}=315)\end{array}$ & $P$-value \\
\hline Gestational age at delivery (wk) & $30.2 \pm 2.7$ & $30.4 \pm 2.8$ & $30.7 \pm 2.6$ & $0.059^{\mathrm{a}}$ \\
\hline Sex (male) & $139(59.4)$ & $91(54.8)$ & $169(53.7)$ & 0.390 \\
\hline Birth weight (kg) & $1.50 \pm 0.50$ & $1.57 \pm 0.57$ & $1.56 \pm 0.52$ & 0.336 \\
\hline Head circumference $(\mathrm{cm})$ & $28.0 \pm 3.1$ & $28.0 \pm 3.4$ & $28.2 \pm 3.1$ & 0.561 \\
\hline Abdominal circumference $(\mathrm{cm})$ & $23.3 \pm 3.3$ & $23.5 \pm 3.3$ & $23.6 \pm 3.2$ & 0.458 \\
\hline SGA & $18(7.7)$ & $18(10.8)$ & $33(10.5)$ & 0.471 \\
\hline 1 min apgar score $<4$ & $39(16.7)$ & $30(18.1)$ & $64(20.4)$ & 0.531 \\
\hline 5 min apgar score $<7$ & $47(20.1)$ & $37(22.3)$ & $61(19.4)$ & 0.756 \\
\hline NICU admission & $231(98.7)$ & $160(96.4)$ & $312(99)$ & 0.965 \\
\hline Duration of NICU stay (day) & $36[1-318]$ & $36[3-226]$ & $30[1-275]$ & $0.136^{\mathrm{a}}$ \\
\hline Ventilator treatment & $126(54.1)$ & $93(56.0)$ & $172(54.6)$ & 0.926 \\
\hline Duration of assisted ventilation (day) & $6[1-317]$ & $4[1-121]$ & 4 [1-213] & 0.291 \\
\hline Neonatal mortality & $9(3.8)$ & $7(4.2)$ & $15(4.8)$ & 0.870 \\
\hline Respiratory distress syndrome & $96(41.0)$ & $60(36.1)$ & $118(37.5)$ & 0.561 \\
\hline Bronchopulmonary dysplasia & $49(21.0)$ & $29(17.5)$ & $59(18.7)$ & 0.648 \\
\hline Periventricular leukomalacia & $8(3.4)$ & $6(3.6)$ & $9(2.9)$ & 0.883 \\
\hline Intraventricular hemorrhage ( $\geq$ grade 3 ) & $6(2.6)$ & $5(3.0)$ & $8(2.5)$ & 0.158 \\
\hline Retinopathy of prematurity ( $\geq$ grade 3 ) & $15(6.4)$ & $12(7.2)$ & $16(5.1)$ & 0.609 \\
\hline Necrotizing enterocolitis ( $\geq$ stage 2 ) & $6(2.6)$ & $2(1.2)$ & $7(2.2)$ & 0.481 \\
\hline Suspected or proven early sepsis & $10(4.3)$ & $18(10.8)$ & $24(7.6)$ & 0.044 \\
\hline Suspected or proven late sepsis & $17(7.3)$ & $10(6.0)$ & $29(9.2)$ & 0.435 \\
\hline Composite morbidity $^{b}$ & $121(51.7)$ & $88(53.0)$ & $160(50.8)$ & 0.898 \\
\hline
\end{tabular}

Bolding denotes significant findings.

Data are presented by mean \pm standard deviation or number (\%) or median [range].

SGA, small-for-gestational-age; NICU, neonatal intensive care unit.

a Jonckheere-Terpstra test, $P<0.05$.

${ }^{b}$ Defined as having more than one of the following: neonatal death, respiratory distress syndrome, bronchopulmonary dysplasia, periventricular leukomalacia, intraventricular hemorrhage ( $\geq$ grade 3 ), retinopathy of prematurity ( $\geq$ grade 3 ), necrotizing enterocolitis ( $\geq$ stage 2 ), suspected or proven early and late neonatal sepsis.

그러나 산전 부신피질호르몬 비사용군, 일회 사용군, 다회 사용군 및 각 체질량지수군 간에 임신부 특성 및 임신 결과가 다르므로 이를 보정 하기 위해 다변량 분석을 시행하였다(Table 6). 입원 시 임신 주수, 분만 시 임신 주수, 분만 주수, 입원 적응증의 차이, 임신성 고혈압성 질환, 임 신성 당뇨, 임상적 융모양막염, 제왕절개수술 등 단변량 분석에서 각 군 별로 유의한 차이가 있었던 교란인자들을 독립 변수로 하여 다중로짓회 귀분석을 시행한 결과 산전 부신피질호르몬의 일회 사용과 다회 사용은 각각 신생아 호흡곤란증후군의 발생 빈도를 의미 있게 감소시켰다. 그 러나 임신부의 체질량지수는 신생아 호흡곤란증후군의 발생 빈도와 통 계적으로 유의한 상관관계가 없었다.

\section{고 찰}

본 연구는 임신부의 비만도에 따라 산전 부신피질호르몬의 효과를 비 교해보기 위해 신생아의 호흡곤란증후군 및 신생아 복합 합병증의 발생 빈도를 비교 분석하고 또한 산전 부신피질호르몬의 일회 요법에 비하여 다회 요법이 조산아의 예후에 어떠한 차이를 보이는지를 비교 분석하고 자 한 것이다. 본 연구의 결과에 따르면 산전 부신피질호르몬을 다회 투 여 받은 임신부에게서 출생한 신생아는 비사용군 또는 일회 투여군에 비해 신생아 호흡곤란증후군의 발생 빈도와 인공호흡기 사용률 및 신생 아 복합 합병증의 발생 빈도가 유의하게 감소한 것으로 나타났다. 그러 나 전반적인 조산아의 신생아 예후는 임신부의 체질량지수에 따른 차이 가 없었다. 


\title{
KOREAN JOURNAL OF OBSTETRICS \& GYNECOLOGY
}

\author{
KJOG Vol. 54, No. 10, 2011
}

Table 5. Incidence of respiratory distress syndrome and composite morbidity according to maternal body mass index and antenatal steroid exposure

\begin{tabular}{|c|c|c|c|c|}
\hline & $\begin{array}{l}\text { Non-user } \\
(n=244)\end{array}$ & $\begin{array}{c}\text { Single-course } \\
(n=377)\end{array}$ & $\begin{array}{l}\text { Multiple-course } \\
\quad(n=94)\end{array}$ & $P$-value \\
\hline \multicolumn{5}{|l|}{ RDS } \\
\hline Group $1\left(\mathrm{BMl}<23 \mathrm{~kg} / \mathrm{m}^{2}\right)(\mathrm{n}=234)$ & $37 / 76(48.7)$ & $56 / 127(44.1)$ & $3 / 31(9.7)$ & 0.001 \\
\hline Group $2\left(\mathrm{BMI} 23-24.9 \mathrm{~kg} / \mathrm{m}^{2}\right)(\mathrm{n}=166)$ & $25 / 56(44.6)$ & $33 / 91(36.3)$ & $2 / 19(10.5)$ & 0.028 \\
\hline Group $3(B M I \geq 25$ kg/m²) $(n=315)$ & $46 / 112(41.1)$ & $66 / 159(41.5)$ & $6 / 44(13.6)$ & 0.002 \\
\hline$P$-value & 0.586 & 0.506 & 0.857 & \\
\hline \multicolumn{5}{|l|}{ Composite morbidity } \\
\hline Group $1\left(\mathrm{BMI}<23 \mathrm{~kg} / \mathrm{m}^{2}\right)(\mathrm{n}=234)$ & $42 / 76(55.3)$ & 70/127 (55.1) & $9 / 31(29.0)$ & 0.025 \\
\hline Group $2($ BMI 23-24.9 kg/m²) $(n=166)$ & $36 / 56(64.3)$ & $46 / 91(50.5)$ & $6 / 19(31.6)$ & 0.037 \\
\hline Group $3\left(\mathrm{BMI} \geq 25 \mathrm{~kg} / \mathrm{m}^{2}\right)(\mathrm{n}=315)$ & $54 / 112(48.2)$ & $92 / 159(57.9)$ & $14 / 44(31.8)$ & 0.007 \\
\hline$P$-value & 0.139 & 0.535 & 0.965 & \\
\hline
\end{tabular}

Bolding denotes significant findings.

RDS; respiratory distress syndrome, BMl; body mass index

Table 6. Relationship between the incidence of respiratory distress syndrome and independent variables analyzed by multiple logistic regression

\begin{tabular}{|lccr|}
\hline \multicolumn{1}{|c}{ Variables } & OR & 95\% Cl & \multicolumn{1}{c|}{$\boldsymbol{P}$-value } \\
\hline Gestational age at admission (wk) & 0.793 & $0.677,0.929$ & 0.004 \\
Gestational age at delivery (wk) & 0.631 & $0.511,0.781$ & $<0.001$ \\
Birth weight $(\mathrm{kg})$ & 1.563 & $0.748,3.265$ & 0.235 \\
Preterm premature rupture of membranes & 1.039 & $0.637,1.694$ & 0.879 \\
Hypertension & 0.441 & $0.153,1.274$ & 0.131 \\
Gestational diabetes & 1.079 & $0.411,2.834$ & 0.878 \\
Cesarean delivery & 2.326 & $1.475,3.667$ & $<0.001$ \\
Clinical chorioamnionitis & 1.355 & $0.608,3.024$ & 0.457 \\
Maternal BMI (kg/m ${ }^{2}$ ) & 0.973 & $0.913,1.038$ & 0.408 \\
Single-course of ACS & 0.593 & $0.373,0.942$ & 0.027 \\
Multiple-course of ACS & 0.085 & $0.034,0.213$ & $<0.001$ \\
\hline
\end{tabular}

Bolding denotes significant findings.

OR; odds ratio, Cl; confidence interval, BMI; body mass index, ACS; antenatal corticosteroid.

현재까지 보고된 임신부의 체질량지수에 따른 산전 부신피질호르 몬의 효과 또는 혈중 농도에 대한 연구는 Gyamfi 등[12]이 2010년 발 표한 45명의 임신부의 혈중 및 탯줄의 호르몬 농도를 비교한 연구와 Hashima 등[13]이 산전 부신피질호르몬을 투여한 183명의 임신부를 대상으로 임신전 체질량지수와 조산 신생아의 합병증을 분석한 두 가지 연구가 있다. 두 연구 모두에서 본 연구와 마찬가지로 임신부의 체질량 지수와 산전 부실피질 호르몬의 효과 및 혈중 농도는 차이가 없는 것으 로 나타났다. 본 연구와 가장 유사한 Hashima 등[13]의 연구와 본 연구 의 차이점은 임신전 체질량지수가 아닌 산전 부신피질호르몬을 투여할 당시의 체질량지수를 기준으로 한 점이다. 임신전 체질량지수도 중요한 변수이지만, 약물투여 시의 임신 주수 및 임신중 체중증가 등에 따라 임 신부의 체중이 달라질 수 있고, 약물을 투여할 당시의 체질량지수가 약 의 조직 분포에 영향을 미친다는 점을 고려할 때 산전 부신피질호르몬
의 효과를 분석하는데 있어 임신전 체질량지수보다 투여 당시의 체질량 지수가 더 적합하다고 할 수 있겠다.

이 연구에서 체질량지수는 한국비만협회에서 제안한 표준치를 참고 로 하였다. 이 체질량지수는 일반 인구를 기준으로 하였기 때문에 임신 부의 비만도를 평가하는 데 있어서는 적합하지 않을 수 있다. 그러나 현 재 정립되어 있는 임신부의 비만도 평가 기준이 없으므로 기존의 일반 인구의 체질량지수를 참고로 하였다. 그러나 본 결과에서 체질량지수에 따른 산전 부신피질호르몬의 효과가 차이가 없는 것으로 나타났으므로 체질량지수를 임신부의 기준으로 재분류하여 연구할 필요는 없을 것으 로 생각된다. 또한 이 연구에서는 세 군 간에 입원 당시의 임신 주수, 입 원 적응증, 입원-분만 잠복기, 임상적 융모양막염, 제왕절개수술률, 고 혈압 및 임신성 당뇨의 유무의 차이가 통계적으로 차이가 있었다. 이러 한 인자들, 특히 입원 당시의 입원 주수는 조산아 예후에 영향을 미칠 


\section{KOREAN JOURNAL OF OBSTETRICS \& GYNECOLOGY}

Eun Ju Jo, et al. The effect of ACS and maternal BMI

수 있으므로 신생아 호흡곤란증후군을 포함한 신생아의 예후에 영향을 미치는 교란인자로 작용할 수 있다. 그러나 위의 교란인자를 보정한 이 후에도 임신부의 체질량지수는 신생아 호흡곤란증후군의 발생 빈도에 영향을 주지 않았다.

현재까지 조산의 합병증을 줄이기 위해 24주에서 34주 사이의, 7 일 이내에 조산의 위험이 있는 임신부에게 산전 부신피질호르몬을 일회 요 법으로 투여하는 것이 현재까지 가장 보편화되어 있는 방법이다[14,15]. 그러나 1회 투여 후 7일 이상이 경과된 이후에도 조산의 위험이 지속되 거나 재발한 경우 반복 또는 다회 투여를 하는 것이 조산아 예후를 호 전시킬 수 있는지에 대해선 아직 뚜렷한 결론이 없는 실정이다. 2000 년 NICHD Consensus Development Conference에서는 충분한 연구 결 과가 나오기 전까지는 부신피질호르몬의 다회 투여를 보류하라는 권고 를 한 바 있다[14]. 그러나 최근 여러 무작위 대조군 연구 및 메타분석에 서 산전 부신피질호르몬의 다회 요법이 신생아의 호흡기계 합병증을 감 소시킬 수 있다는 연구결과가 있어[16-18] 지난 2011년 2월 미국산부 인과학회에서는 초회 산전 부신피질호르몬 투여 후 2주 이상 경과하였 는데도 조산의 위험이 재발하거나 지속되는 경우 1 주 이내 분만할 가능 성이 높은 임신부에게 32주 6일 이전에는 1회의 반복 투여를 고려할 수 있다고 하였다. 그러나 반복적인 다회 투여에 대한 상반된 조산아 예후 에 대한 연구 결과와 모체 또는 신생아의 감염성 질환의 증가 위험이 있 으므로 3회 이상의 다회 투여는 추천되지 않는다고 발표하였다[4]. 본 연구에서도 산전 부신피질호르몬에 다회 노출된 조산아는 1 회 투여에 비해 융모양막염이나 신생아 패혈증과 같은 감염성 합병증 또는 출생 체중의 감소 등과 같은 위험은 증가시키지 않으면서 신생아 호흡곤란증 후군뿐 아니라 기관지-폐이형성증, 괴사성 장염의 발생 빈도가 유의하 게 감소하였고 인공호흡기 사용 빈도도 낮다는 결과가 나왔다.

본 연구는 신생아의 단기적인 예후만을 추적했을 뿐, 장기적으로 유 아기 또는 소아기에 어떠한 예후를 나타내는지에 대해서는 다루지 않은 한계점과 임신부의 감염의 위험을 증가시킬 뿐 아니라 시상하부-뇌하 수체-아드레날린축에 미치는 영향은 고려하지 않은 점, 전향적 무작위 연구가 아니고 의무기록에 의존한 후향적 연구라는 점에서 한계점을 지 니고 있다.

결론적으로 본 연구 결과 산전 부신피질호르몬의 투여, 특히 다회 투 여는 조산아의 신생아 호흡곤란증후군의 발생 빈도, 인공호흡기 사용률 및 신생아 복합 합병증의 발생 빈도의 감소와 유의한 관계가 있으나 임 신부의 체질량지수에 따른 차이는 없는 것으로 나타났다. 따라서 임신 부의 체질량지수를 기준으로 산전 부신피질호르몬의 용량을 조절하는 것은 현재로선 불필요할 것으로 생각되나 향후 더 많은 임신부를 대상 으로 한 전향적 연구가 필요할 것으로 생각된다.

\section{References}

1. Liggins GC, Howie RN. A controlled trial of antepartum glucocorticoid treatment for prevention of the respiratory distress syndrome in premature infants. Pediatrics 1972;50:515-25.

2. Crowley PA. Antenatal corticosteroid therapy: a meta-analysis of the randomized trials, 1972 to 1994. Am J Obstet Gynecol 1995; 173:322-35.

3. Effect of corticosteroids for fetal maturation on perinatal outcomes. NIH Consens Statement 1994;12:1-24.

4. ACOG Committee on Obstetric Practice. ACOG Committee Opinion No. 475: Antenatal corticosteroid therapy for fetal maturation. Obstet Gynecol 2011;117:422-4.

5. Ballabh P, Lo ES, Kumari J, Cooper TB, Zervoudakis I, Auld PA, et al. Pharmacokinetics of betamethasone in twin and singleton pregnancy. Clin Pharmacol Ther 2002;71:39-45.

6. Cho HJ, Seo ES, Song SE, Jung KL, Choi SJ, Oh SY, et al. The effect of multiple courses of antenatal corticosteroid therapy on perinatal outcome of the preterm neonates. Korean J Obstet Gynecol 2007;50:741-50.

7. Choi SJ, Song SE, Seo ES, Oh SY, Kim JH, Roh CR. The effect of single or multiple courses of antenatal corticosteroid therapy on neonatal respiratory distress syndrome in singleton versus twin pregnancies. Aust N Z J Obstet Gynaecol 2009;49:173-9.

8. Al-Yatama MK, Al Essa M, Omu AE, Al-Shamali I, Egbase P, Rashwan N. Effect of repeated doses of dexamethasone on the incidence and severity of respiratory distress syndrome in multifetal gestation between 24 and 34 weeks. Gynecol Obstet Invest 2001;52:26-33.

9. Quist-Therson EC, Myhr TL, Ohlsson A. Antenatal steroids to prevent respiratory distress syndrome: multiple gestation as an effect modifier. Acta Obstet Gynecol Scand 1999;78:38892.

10. Turrentine MA, Wilson PD, Wilkins IA. A retrospective analysis of the effect of antenatal steroid administration on the incidence of respiratory distress syndrome in preterm twin pregnancies. Am J Perinatol 1996;13:351-4.

11. Gibbs RS, Blanco JD, St Clair PJ, Castaneda YS. Quantitative bacteriology of amniotic fluid from women with clinical intraamniotic infection at term. J Infect Dis 1982;145:1-8.

12. Gyamfi C, Mele L, Wapner RJ, Spong CY, Peaceman A, Sorokin $Y$, et al. The effect of plurality and obesity on betamethasone concentrations in women at risk for preterm delivery. Am J Obstet Gynecol 2010;203:219.e1-5.

13. Hashima JN, Lai Y, Wapner RJ, Sorokin Y, Dudley DJ, Peaceman $A$, et al. The effect of maternal body mass index on neonatal outcome in women receiving a single course of antenatal corticosteroids. Am J Obstet Gynecol 2010;202:263.e1-5.

14. Antenatal corticosteroids revisited: repeat courses. NIH Cons- 


\section{KOREAN JOURNAL OF OBSTETRICS \& GYNECOLOGY}

KJOG Vol. 54, No. 10, 2011

ens Statement 2000;17:1-18.

15. Roberts D, Dalziel S. Antenatal corticosteroids for accelerating fetal lung maturation for women at risk of preterm birth. Cochrane Database Syst Rev 2006;3:CD004454.

16. Garite TJ, Kurtzman J, Maurel K, Clark R; Obstetrix Collaborative Research Network. Impact of a 'rescue course' of antenatal corticosteroids: a multicenter randomized placebocontrolled trial. Am J Obstet Gynecol 2009;200:248.e1-9.
17. Wapner RJ, Sorokin Y, Thom EA, Johnson F, Dudley DJ, Spong $C Y$, et al. Single versus weekly courses of antenatal corticosteroids: evaluation of safety and efficacy. Am J Obstet Gynecol 2006;195:633-42.

18. Crowther CA, Harding JE. Repeat doses of prenatal corticosteroids for women at risk of preterm birth for preventing neonatal respiratory disease. Cochrane Database Syst Rev 2007;(3):CD003935.

\section{임산부의 체질량지수에 따라 산전 부신피질호르몬 치료가 신생아 호흡곤란증후군의 발생에 미치는 영향}

\section{성균관대학교 의과대학 삼성서울병원 산부인과}

조은주, 곽혜민, 지현영, 차현화, 최석주, 오수영, 노정래, 김종화

\section{목적}

임산부의 체질량지수(body mass index, BMI)에 따라 산전 부신피질호르몬의 투여가 조산아의 신생아 호흡곤란증후군의 발생 빈도에 미치 는 영향을 분석하고자 하였다.

\section{연구방법}

임신 24주-34주에 조산한 715명의 임산부들을 대상으로 후향적 고찰을 시행하였다. 연구대상은 부신피질호르몬 투여 유무 및 횟수에 따라 부신피질 비사용군(244명), 일회 사용군(377명), 다회 사용군(94명)으로 각각 분류하고 입원 시 임산부의 체질량지수에 따라 1 군 (BMl<23.0 kg/m², 234명), 2군(BM 23.0-24.9 kg/m², 166명), 3군(BMI $\geq 25.0 \mathrm{~kg} / \mathrm{m}^{2}, 315$ 명)으로 재분류하였다.

\section{결과}

신생아 호흡곤란증후군의 발생 빈도는 비사용군에 비해 사용군이 유의하게 낮았으며, 다회 사용군에서 가장 낮은 발생 빈도를 보였다 (44.3\% vs. $41.1 \%$ vs. $11.7 \%, P<0.001)$. 그러나 임산부의 체질량지수군에 따른 세 군 간에 신생아 호흡곤란증후군의 발생빈도는 유의한 차이가 없었다. 다중로짓 회귀분석 결과 산전 부신피질호르몬 투여는 신생아 호흡곤란증후군의 위험을 의미 있게 감소시켰다. 그러나 임 산부의 체질량지수는 각 부신피질호르몬 투여군에서 신생아 호흡곤란증후군의 발생 빈도와 상관이 없었다( $P$ for interaction $=0.690)$.

\section{결론}

산전 부신피질호르몬 투여, 특히 다회 요법은 신생아 호흡곤란증후군의 위험을 감소시켰으나 임산부의 체질량지수에 따른 차이는 없었다.

중심단어: 조산, 산전 부신피질호르몬, 신생아 호흡곤란증후군, 체질량지수 